\title{
STATUS OF USING MEDICINAL PLANTS IN NAM PUNG COMMUNE, BAT XAT DISTRICT, LAO CAI PROVINCE
}

\author{
Trinh Dinh Kha ${ }^{1}$, Nguyen Thi Thu Hien ${ }^{2 *}$, Dam Van Vinh ${ }^{2}$ \\ ${ }^{I} T N U$ - University of Sciences, \\ ${ }^{2} T N U$ - University of Forestry and Agriculture
}

\begin{abstract}
This research was conducted to assess the diversity of medicinal plant resources in Nam Pung commune, Bat Xat district, Lao Cai province. The methods used for collecting data were the method of specimen collection, interview method, identification of the species name, method of medicinal plant resources diversity assessment, method of endangered medicinal plant level assessment. The results of research have identified initially 75 species of medicinal plants of 73 genera and 47 families which have been used by the Dao ethnic minority community for diseases prevention and treatment. There are 5 main life forms of the medicinal plants: herbaceous, shrubs, vines, small wood trees and moderate wood trees. The tree distribution is often in many types of habitat: forests, gardens, hills and along streams. Among the components used as medicine, the whole plant, leaves and stem parts are most often used. The results show that there are 11 groups of diseases that could be cured by the experience of using medicinal plants of Dao ethnic community in the study area, of which 4 groups of diseases occupy the highest rate: digestive diseases, osteoarthritis disease, weather sickness, and wound diseases. There are 4 endangered medicinal plants, namely Anoectochilus setaceus Blume, Stephania sinica Diels, Callerya speciosa (Champ. ex Benth.) Schot, and Gynostemma pentaphyllum (Thunb.) Makino.

Keywords: Diversity; medicinal plants; Nam Pung commune; Bat Xat district; Lao Cai province.
\end{abstract}

Received: 16/3/2020; Revised: 27/4/2020; Published: 28/4/2020

\section{THỰC TRẠG SỬ DỤNG CÂY THUỐC TẠI XÃ NẬM PUNG, HUYỆN BÁT XÁT, TỈNH LÀO CAI}

\author{
Trịnh Đình Khá ${ }^{1}$, Nguyễn Thị Thu Hiền ${ }^{2 *}$, Đàm Văn Vinh ${ }^{2}$ \\ ${ }^{1}$ Truờng Đại học Khoa học - ĐH Thái Nguyên, \\ ${ }^{2}$ Trưòng Đại học Nông Lâm - ĐH Thái Nguyên
}

\section{TÓM TẮT}

Nghiên cứu này được tiến hành nhằm đánh giá thực trạng nguồn tài nguyên cây thuốc được sử dụng trong cộng đồng dân tộc Dao tại xã Nậm Pung, huyện Bát Xát, tỉnh Lào Cai. Các phương pháp sử dụng gồm có: thu thập mẫu vật, phỏng vấn, định danh tên loài, đánh giá tính đa dạng nguồn tài nguyên cây thuốc và đánh giá mức độ nguy cấp của các loài cây thuốc. Kết quả nghiên cứu bước đầu đã xác định được 75 loài cây thuốc thuộc 73 chi, 47 họ được cộng đồng dân tộc ở khu vực nghiên cứu sử dụng trong phòng và chữa bệnh cho người dân. Cây thuốc thuộc 5 dạng sống chính gồm: thân thảo, cây bụi, dây leo, cây gỗ nhỏ và cây gỗ trung bình. Cây thường phân bố ở các dạng sinh cảnh như: sống ở vườn, đồi, rừng và sống ven suối. Trong các bộ phận được sử dụng làm thuốc thì bộ phận cả cây, lá và thân được sử dụng nhiều nhất. Nghiên cứu đã xác định được 11 nhóm bệnh được chữa trị bằng kinh nghiệm sử dụng cây thuốc của cộng đồng dân tộc Dao tại khu vực nghiên cứu, trong đó có 4 nhóm bệnh chiếm tỷ lệ cao nhất: bệnh về tiêu hóa, bệnh về xương khớp, bệnh do thời tiết, bệnh về vết thương. Có 4 loài cây thuốc cần được bảo vệ đã được ghi nhận gồm: Anoectochilus setaceus Blume - Lan kim tuyến, Stephania sinica Diels Bình vôi tán ngắn, Callerya speciosa (Champ. ex Benth.) Schot - Cát sâm, và Gynostemma pentaphyllum (Thunb.) Makino - Giảo cổ lam.

Từ khóa: Cây thuốc; đa dạng cây thuốc; Nậm Pung; Bát Xát; Lào Cai.

Ngày nhận bài: 16/3/2020; Ngày hoàn thiện: 27/4/2020; Ngày đăng: 28/4/2020

* Corresponding author. Email: nguyenthithuhien@tuaf.edu.vn
DOI: https://doi.org/10.34238/tnu-jst.2020.05.2831

http://jst.tnu.edu.vn; Email: jst@tnu.edu.vn 


\section{Introduction}

Vietnam is a country with three-quarters of mountainous areas, rich in medicinal plant resources and diversity of ethnic groups (54 ethnic groups across the country). Most of the groups are ethnic minorities with about 24 million people accounted for over one - third of the Vietnamese populations [1]. Such diversity of the people, soil, climate, customs and culture in each ethnic community has provided great medicinal knowledge and experience in using plants as medicine.

Lao Cai has rich natural resources, humid tropical climate, rich in diverse vegetation and is home to 14 ethnic minorities such as Dao, H'Mong, Ha Nhi, Day, etc. For a long time, ethnic minorities in Lao Cai province have been able to cure diseases by using medicinal plants, each ethnic group has different experience in plan medicine reflecting their identifies [2], [3]. Among them, the Dao ethnic minority in Nam Pung Commune, Bat Xat District also have unique experiences in medicinal plants. However, nowadays forest area is decreasing and the situation of harvesting and trading is complicated causing a decline in medicinal plant resources. In addition, though the medicine has been used by the Dao ethnic for a long time in preventing and treating effectively some diseases, the biological activity and scientific knowledge of the medicine have not been studied and proven by science. This study presents the results of survey on the status of the use of medicinal plants in the study area. This is the first study to include valuable ethnographic information about medicinal plants used by the local Dao people of the Nam Pung Community, Bat Xat District, Lao Cai Province.

\section{Research methodology}

2.1. Methods for collecting secondary data: Inheriting documents on natural, socioeconomic conditions in the study area and materials related to the research issue.

\subsection{Methods of collecting primary data:}

Methods of community investigation: At the study area, interviewed herdsmen, cynics, people having medicinal using experience and using traditional medicine remedies of ethnic communities. The research's questionnaire was based on the community's medicinal plants questionnaire and the questionnaire of the Institute of Medicinal Materials [4]. Collected information about medicinal plants includes common name, ethnicity; model number; life forms; living environment; used parts as medicine (stems, roots, flowers, fruits, seeds, etc.); the value each medicinal plant.

Method of specimen collection: Specimens were collected according to Nguyen Nghia Thin's method in 1997 [5].

Method of identifying species names: Identification of the plant species in two main steps: (i) identification in the field; (ii) using the knowledge and experience of experts and reliable sources that have been re-examined, including methods of Pham Hoang Ho [6], Vo Van Chi [7]; Do Tat Loi [8] and Checklist of plant species in Vietnam [9].

Method of medicinal plant resources diversity assessment: Based on Nguyen Nghia Thin's method [10].

Method of endangered medicinal plants level assessment: Identifying preserved medicinal plants in the study area according to Vietnam Red Book [11], Decree 06 of the Government of Vietnam [12], Red List of Vietnamese Medicinal Plants in the Medicinal Plant Handbook to protect in Vietnam [13].

\section{Results}

\subsection{Taxonomic diversify of medicinal plant resources}

Researching medicinal plants was based on the experience of Dao ethnic minority in the study area and found 75 species of plants that the Dao ethnic used as medicine including 73 genera, 47 families (Table 1). 
Table 1. Number of discovered medicinal plants in Nam Pung commune, Bat Xat district, Lao Cai province

\begin{tabular}{clrcrrrr}
\hline \multirow{2}{*}{ No. } & \multirow{2}{*}{ Taxonomic } & \multicolumn{2}{c}{ Family } & \multicolumn{2}{c}{ Genus } & \multicolumn{2}{c}{ Species } \\
\cline { 3 - 7 } & & Number & percentage & Number & percentage & Number & percentage \\
\hline 1 & Lycopodiophyta & 1 & 2.13 & 2 & 2.74 & 2 & 2.67 \\
2 & Pteridophyta & 2 & 4.26 & 2 & 2.74 & 2 & 2.67 \\
3 & Magnoliophyta & 44 & 93.62 & 69 & 94.52 & 71 & 94.67 \\
- & Liliopsida & 8 & 76.60 & 11 & 79.45 & 11 & 80.00 \\
- & Magnoliopsida & 36 & 17.02 & 58 & 15.07 & 60 & 14.67 \\
& Total & $\mathbf{4 7}$ & $\mathbf{1 0 0 . 0 0}$ & $\mathbf{7 3}$ & $\mathbf{1 0 0 . 0 0}$ & $\mathbf{7 5}$ & $\mathbf{1 0 0 . 0 0}$ \\
\hline
\end{tabular}

Table 1 shows that 2 species in $37 / 75$ accounting for $49.33 \%$ of the total Lycopodiophyta have been used as medicine, Lycopodiella cemua and Selaginella involvens (Sw.) Spring, accounting for $2.67 \%$ of the total number of found species; there were 2 species in Pteridophyta: Equisetum debile Roxb, Lygodium japoniam Thunb. Sw.; 71 species in Magnoliophyta have been found $(94,67 \%$ of total species) in 69 genera (accounting for $94,52 \%$ of the total) and 44 families accounting for $93,62 \%$ of the total). This result reveals that the flora in the study area are mainly Magnoliophyta, which are common in the surrounding hamlets, hills, rivers and streams. Therefore, these are also the more common species having been chosen to make drugs than other plants.

Magnoliophyta plays a particularly important role in the medicinal plants, especially for the Magnoliopsida. Magnoliopsida has an predominant number of the families, genera, species used as medicine over the Liliopsida. Magnoliopsida has 60/71 species; 58/69 genera and 36/44 families. The valuable species are: Cronton tonkinensis Gagnep used to treat stomachache, indigestion; Gynostemma pentaphylum used to treat high blood pressure, cardiovascular, anti-fatigue; Aralia cordat Thunb used to treat osteoarthritis and skin; Morinda officinalis How used to treat osteoarthritis; Fallopia multiflora (Thunb.) Haraldson, etc.

\subsection{Diversity of life forms of medicinal plant resources}

The diversity of life forms of medicinal plants in the study area is shown in Figure 1.

Figure 1 shows that most of the medicinal plants used by the Dao ethnic community in the study area are herbaceous plants, with number of medicinal plants collected and the majority belong to the family Poaceae with some species including Anoectochilus setaceus Blume for the nervous system and liver disease; Ophiopogon japonicus (L. f.) Ker-Gawl cures cough; Saururus chinensis (Lour.) Hort. Loud ex cure osteoarthritis, etc.

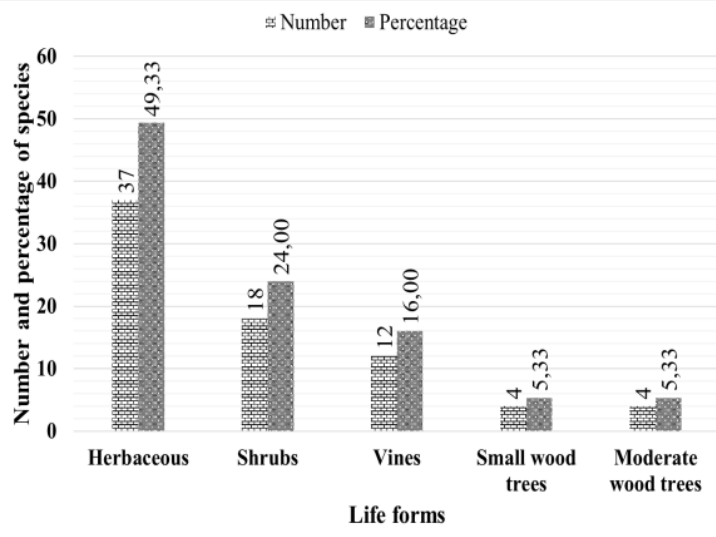

Figure 1. Diversity of life forms of medicinal plants in Nam Pung commune, Bat Xat district, Lao Cai province

The following life forms are shrubs with $18 / 75$ species $(24 \%)$ and vines life forms with 12/75 species (16\%). Some species include Urena lobata L. used to treat rhinitis; Croton tonkinensis Gagnep used to treat diarrhea and stomach disease, etc.

The lowest life forms of medicinal plants are small wood trees and medium wood trees, reaching 4/75 tree species (5.33\%). Some species are named Schima wallichii (DC.) Korth which is able to cool the liver; Lansium domesticum Correa which is used to treat pimples, etc.

In general, the above data prove that the experience of using medicinal plants as medicine for the treatment of Dao people in the study area is very diverse and abundant. 


\subsection{Diversity of habitat of medicinal plant resources}

Habitats classification is based on terrain, land, climate where the medicinal plants grow. Medicinal plants in the study area have the following habitats: (i) hills: trees live in hills, wild hills, dusty fields, foothills; (ii) gardens: trees live in the garden, the pond, around the village, (iii) forests: trees live in dense forest, secondary forest, forest edge; (iv) near streams, rivers: trees live near flowing water, near streams, rivers, wetlands.

The data in Table 2 show that, the number of species distributed in the gardens is relatively high with 41/75 species (accounting for $54.67 \%$ of the total number of collected species. This proves that people in the study area are aware of the value and importance of medicinal plants when bringing medicinal plants to expand the model of medicinal plants at the garden habitat to provide medicinal resources. The second habitat is hills with the number of trees distributed 31/75 species (accounting for 41.33\%); followed by medicinal plants living in the forest with 30/75 species (accounting for $40.00 \%)$. At least, the medicinal plants found along the stream are only $7 / 75$ species (accounting for $9.33 \%$ ).

Through assessing the diversity of the distribution of trees according to habitats, it shows that the medicinal plants have very diverse living conditions and different distribution ranges. Studying the habitat of each species is very important for the conservation and sustainable use of medicinal ingredients.

\subsection{Diversify of used parts of medicinal plants}

The results of using the medicinal plants' parts as medicine based on the experience of the Dao ethnic minority in study area are shown in Table 3.

Table 2. Distribution of medicinal plants in different habitats in Nam Pung commune, Bat Xat district, Lao Cai province

\begin{tabular}{clcc}
\hline No. & Living environment & Species & Percentage \\
\hline 1 & Gardens & 41 & 54.67 \\
2 & Hills & 31 & 41.33 \\
3 & Forests & 30 & 40.00 \\
4 & Along streams & 7 & 9.33 \\
\hline
\end{tabular}

(Note: The percentages in the table are more than 100\% as some species can live in different habitats)

Table 3. Diversity of plants' parts used as medicine in Nam Pung commune, Bat Xat district, Lao Cai province

\begin{tabular}{clcc}
\hline No. & Used parts & Species & Percentage \\
\hline 1 & Whole plant & 33 & 44.00 \\
2 & Leaves & 24 & 32.00 \\
3 & Stem & 14 & 18.67 \\
4 & Roots & 11 & 14.67 \\
5 & Bark & 5 & 6.67 \\
6 & Fruits & 3 & 4.00 \\
7 & Sap & 3 & 4.00 \\
\hline
\end{tabular}

(Note: The percentages are more than $100 \%$ as some species may use different components for drug use)

Table 3 shows that Dao ethnic people use seven parts of the medicinal plants. In particular, whole plant is the most common part used for medicine with 33/75 species (accounting for $44.00 \%$ of the total species). The second largest category is the use of leaves with $24 / 75$ species (accounting for $32.00 \%$ of total species). It can be said that the use of medicinal leaves will help the medicinal plants to be used for a long time, without reducing and protecting the number of medicinal plants. The next is the stem section with 14/75 species of medicinal plants used (accounting for 18.67\%); roots with 11/75 medicinal plant species (accounting for 14.67\%); and the lowest part are fruits and sap with $3 / 75$ species (accounting for $4.00 \%$ ). 
From the above results, we can see that using whole parts of the plant or stem or roots as medicine will be very detrimental in conserving the genetic resources of medicinal plants, so we need to develop and implement methods of growing medicinal plants with parts used are whole plants or stems or roots, to conserve and sustainably develop medicinal plant resources in the study area.

\subsection{Diversity of medicinal uses of medicinal plant resources}

The results of the survey on the diversity of medicinal plants are shown in Table 4.

Table 4. Proportion of species to treat specific diseases

\begin{tabular}{clrc}
\hline No. & \multicolumn{1}{c}{ Treatment disease group } & Species & Percentage \\
\hline 1 & Diseases of the digestive system (abdominal pain, stomach, hemorrhoids, etc) & 17 & 22.67 \\
2 & Diseases of the joints (rheumatism, back pain, bone pain, rheumatism, etc) & 15 & 20.00 \\
3 & Weather diseases (cough, fever, cold, waterpipe, etc.) & 12 & 16.00 \\
4 & Wound diseases (infection, pain relief, burns, ...) & 11 & 14.67 \\
5 & Liver disease (cirrhosis, liver detoxification, hepatitis, etc) & 9 & 12.00 \\
6 & Heat bar, Detoxification & 7 & 9.33 \\
7 & Kidney disease (kidney stones, kidney failure, diuretic, ...) & 6 & 8.00 \\
8 & Supplement (health, blood, liver, etc.) & 5 & 6.67 \\
9 & Shower medicine & 5 & 6.67 \\
10 & Diseases of the circulatory system (blood fats, blood pressure, heart, etc) & 4 & 5.33 \\
11 & Physiological diseases, women's disease (infertility, puerperal, ...) & 4 & 5.33 \\
\hline
\end{tabular}

The data in table 4 show that the Dao ethnic community in the study area can use their knowledge and experience on medicinal plants to treat 11 different diseases, including infectious diseases: liver, kidney, heart, bone, joint, intestinal, respiratory tract, etc. The number of medicinal plants used for treatment mainly are 4 specific types of diseases:

- Diseases of the digestive system: there are 17 species out of 75 species (22.67\%). These species are in families such as Rutaceae, Asteraceae, Euphorbiaceae, Poaceae, Euphorbiaceae, Menispermaceae, etc. Some species can be mentioned including: Coix chinensis Todaro ex Bal is used to treat diarrhea; Pluchea indica (L.) Less cures hemorrhoids; Lonicera macrantha (D. Don) Spreng cures the stomach; Sanchezia nobilis Hook. F cure the stomach; Wedelia chinensis (Osbeck) Merr cures hot intestine, etc.

- Diseases of the joints: there are 15 species out of 75 species (accounted for 20.00\%), some popular species are: Fabaceae, Asteraceae, Menispermaceae, Moraceae, etc. Some species can be mentioned as: Lygodium japonicum Thunb. Sw, Tinospora sagittata (Oliv.) Gagnep, Cordyline fruticosa (L.)
Goepp, Saururus chinensis (Lour.) Hort. ex Loud, etc.

- Weather diseases: there are 12/75 species (accounted for $16.00 \%$ ), which are mainly families: Lamiaceae, Zingiberaceae, Lamiaceae, etc. some popular species are: Amomum aromaticum Roxb is used to treat cough and sore throat; Agastache rugosa (Fisch. Et May.) Kuntze cures the flu; Mentha arvenis $\mathrm{L}$.is used to treat coughs, etc.

- Wound diseases: There are 11 out of 75 plant species for infection, pain relief, burns, etc. The species in this family are: Musaaceae, Commelinaceae, Marantaceae, Malvaceae, etc. Some species are Kalanchoe pinnata (Lamk.) Pers, Urena lobata L., Plantago major L., Lansium domesticum Correa, etc.

In general, the results proved that the experience of using medicinal plants as well as the treatment methods applied by Dao ethnic community in study area is very diversified. In addition, this result also provides a scientific basis for further research on the conservation and sustainable development of medicinal plants and folk remedies of the Dao ethnic community in the study area. 


\subsection{Endangered medicinal plants}

This research has identified the rare medicinal plants that need to be protected in Table 5 .

Table 5. List of preserved medicinal plants in the study area

\begin{tabular}{clccc}
\hline & \multicolumn{1}{c}{ Species } & \multicolumn{3}{c}{ Granted regulations } \\
\cline { 3 - 5 } No. & & $\begin{array}{c}\text { Vietnam } \\
\text { Red Book, } \\
\mathbf{2 0 0 7}\end{array}$ & $\begin{array}{c}\text { Decree 06 of the } \\
\text { Government of } \\
\text { Vietnam }\end{array}$ & $\begin{array}{c}\text { List of red } \\
\text { medicinal plants } \\
\text { in Vietnam }\end{array}$ \\
\hline 1 & Anoectochilus setaceus Blume & EN A1a,c,d & IA & \\
2 & Stephania sinica Diels & & IIA & \\
3 & Callerya speciosa (Champ. ex Benth.) Schot & VU A1a,c,d & & EN A1a,c,d \\
4 & Gynostemma pentaphyllum (Thunb.) Makino & & & \\
\hline
\end{tabular}

There were 4 rare endangered medicinal species belonging to 4 genera and 4 families of Magnoliophyta. There were two species listed in the Vietnam Red Book [11], one species listed in Decree 06 of the Government of Vietnam [12], and two species listed in the Catalog Red Medicinal Plants of Vietnam [13]. Specifically:

- VU level - Vulnerable by Vietnam Red Book, including 1 species: Callerya speciosa (Champ. ex Benth.) Schot belong to the Fabaceae. Callerya speciosa (Champ. ex Benth.) Schot is used for osteoarthritis.

- EN level - Endangered by Vietnam Red Book, including 1 species: Anoectochilus setaceus Blume belongs to family Orchidaceae, which is used to treat nervous system and liver disease. In addition, Anoectochilus setaceus Blume is also a species belonging to IA level - Endangered by Decree 06 of the Government of Vietnam.

- IIA level - May become extinct by Decree 06 of the Government of Vietnam, including 1 species: Stephania sinica Diels belong to the Menispermaceae, which is used to treat skin diseases and abdominal pain.

- EN level - Endangered by the Catalog Red Medicinal Plants of Vietnam, including 1 species: Gynostemma pentaphyllum (Thunb.) Makino belongs to family Cucurbitaceae, used to treat intestinal diseases.
(Note: VU: Vulnerable; EN: Endangered)

\section{Conclusion}

Identified 149 medicinal plants species in the Magnoliophyta, Pteridophyta, Lycopodiophyta. Among them, Magnoliophyta has 71 species belonging to 69 genera and 44 families; Pteridophyta has 2 species belonging to 2 genera and 2 families; Lycopodiophyta has 2 species belonging to 2 genera and 1 family that have medicinal uses.

Life forms: there were 37 species of herbaceous, 18 species of shrubs, 12 species of vines, 4 species of small wood species and 4 species of moderate wood species.

Habitats: mainly medicinal plants used according to the experience of the Dao ethnic community in the study area are living in the garden habitat with 41 species, 31 species in the hill and 30 species in the forest.

Using parts of medicinal plants: Identifying 4 parts of medicinal plants used most by the Dao ethnic minority population in the study area, which are the whole plant, leaves, stems and roots.

There were 11 different groups of patients treated with experience using medicinal plants in the Dao ethnic community in the study area. In which the experience of using medicinal plants of the Dao ethnic community is most concentrated in 4 diseases groups including: diseases of the digestive system, diseases of the joints, weather diseases, wound diseases. 
There were 4 species of medicinal plants in need of conservation, accounting for $5.33 \%$ of the total number of medicinal plants collected, including the species: Anoectochilus setaceus Blume, Stephania sinica Diels, Callerya speciosa (Champ. ex Benth.) Schot, Gynostemma pentaphyllum (Thunb.) Makino.

\section{REFERENCES}

[1]. T. Tran, N. Vu, and V. T. Nguyen, Theory of Traditional Medicine. Medicine Publishing House, Hanoi, 2005.

[2]. H. M. T. Nguyen, Q. K. Quynh, X. T. Do, Medicinal plants in San Sa Ho Commune, Sa Pa District, Lao Cai Province, Proceedings of the 4th national conference on ecology and biological resources (21th october 2011) (ISSN 1859-4425). Natural Science and Technology Publishing House, Hanoi, 2011, pp. 1107-1111.

[3] A. V. T. Nguyen, T. V. Bui, A. N. D. Luu, H. V. Bui, T. P. T. Nguyen, G. T. T. Tran, Medicinal plants utilization pattern of of the ethnic minorities of H'mong and Dao in Y Ty and Den Sang Communes, Bat Xat District, Lao Cai Province, Vietnam, Proceedings of the 6th national conference on ecology and biological resources (21st october 2015) (ISBN 978-604-913-408-1), Natural Science and Technology Publishing House, Hanoi, 2015, pp. 1038-1043.
[4]. Institute of Medicinal Materials, Vietnam Medicinal Resources. Science and Technology Publishing House, Hanoi, 1993.

[5]. N. T. Nguyen, Biodiversity Research Handbook. Agricultural Publishing House, Hanoi, 1997.

[6]. H. H. Pham, Vietnamese Herbs. Young Publishing House, Ho Chi Minh City, 1999.

[7]. V. C. Vo, Dictionary of medicinal plants in Vietnam, Volume 1-2, Hanoi Publishing House, Hanoi, 2012.

[8]. T. L. Do, Vietnamese medicinal plants and herbs. Hanoi Publishing House, Hanoi, 2005.

[9]. T. B. Nguyen (Editor), List of Vietnam Plant Species, Volume 2-3, Agriculture Publishing House, Hanoi, 2003 - 2005.

[10]. N. T. Nguyen, Methods of plant research. Hanoi National University Press, Hanoi, 2007.

[11]. Ministry of Science and Technology, Vietnam Academy of Science and Technology, Vietnam Red Book: Part II Plant. Natural Science and Technology Publishing House, Hanoi, 2007.

[12]. The Government of the Socialist Republic of Vietnam, Decree 06/2019 on the management of endangered, precious and rare forest plants and animals, and the implementation of the Convention on international trade in wild animals and plants Endangered, Hanoi, 2019.

[13]. T. Nguyen, Handbook of medicinal plants that need to be protected in Vietnam. Vietnam Non-Timber Forest Products Network Publishing House, Hanoi, 2007. 